\title{
HISTORIA S. JOANNIS NEPOMUCENI OF 1729 AND ITS CONTEMPORARY TRANSLATION IN THE CONTEXT OF BAROQUE TRANSLATIONS*
}

\author{
ALENA BOČKOVÁ
}

\begin{abstract}
The study focuses on the work of the Jesuit historian Maximilianus Wietrowsky Historia S. Joannis Nepomuceni (1729) and its Czech translation Zpráva historická o životě sv. Jana Nepomuckého [Historical report on the life of St. John of Nepomuk] (1730). It is based on the recent research of early modern Latin and Czech literature which remained part of the European cultural sphere throughout the $17^{\text {th }}$ and $18^{\text {th }}$ century. This gave rise to multilingual (mainly Latin, Czech and German) editions of literary works. Apart from source and translation analysis of both works, the paper also outlines other Wietrowsky's works in a wider cultural and historical context.
\end{abstract}

Keywords: St. John of Nepomuk; Maximilianus Wietrowsky; Neo-Latin Literature; Baroque translations; critical edition

\section{Early Modern translations}

The literary production in the Bohemian lands in the $17^{\text {th }}$ and $18^{\text {th }}$ centuries reflected the new social situation, the changes in spiritual life and the influx of foreign influences (mostly German and Romance). Texts were newly produced in two or three language variations - usually Latin, Czech and German - which could differ somewhat with regard to the presumed recipient. Early Modern translations had a rather interpretive character, with a prevailing tendency to adapt and paraphrase, which made the text more accessible for the domestic reader and accentuated its patriotic / linguistic, religious / morally instructive, educative and, finally, entertainment functions. The translators usually treated the original text with liberty (motivic shifts and alteration of sujet and fabula in order to make the version appropriate for their intended purpose). These alterations served to make the text simpler for less educated readers while, at the same time, achieving a more striking effect by stressing the most remarkable themes and omitting the less attractive

This paper was created with the financial support of the Czech Science Foundation (GA ČR), as a part of standard project no. 17-19400S. 
ones. A typical feature for this period is the accentuation of the text per se and suppression of the personality of the translator - whose name is often absent from the title page and without reference from other sources he usually remains anonymous to this day.

The typology of Early Modern translations stems from the basic distinction between translations into Latin and translations from Latin into vernacular languages. ${ }^{1} \mathrm{~A}$ substantial part of the writings of Maximilianus Wietrowsky (1660-1737), the author of the work in the title of this article, falls under the first type, i.e. translations from vernacular languages into Latin. This study, however, focuses on the genesis and later translation of his Latin work Historia S. Joannis Nepomuceni into Czech and other languages.

\section{Maximilianus Wietrowsky and his works}

Apart from an overview of the life and works of the Jesuit Maximilianus Wietrowsky, the paper will discuss his historiographic method, the context of the creation of his work on St. John of Nepomuk and the results of the translation analysis of Historia S. Joannis Nepomuceni into vernacular languages. A detailed outline of Wietrowsky's career in the Order has been reconstructed with the aid of Jesuit sources - mainly manuscript ones. ${ }^{2}$ Wietrowsky studied theology in Rome, taught philosophy and theology in Olomouc and Prague and later served as Rector of the college of Nové Město in Prague. His work there was accompanied by unspecified disputes and, probably because of them, he remained in the lower strata of the Order's administration. From 1718 he worked as an assessor of the Prague Archbishop Consistory and in 1718-1731 served as the confessor to the Archbishop of Prague, Ferdinand Khuenburg. ${ }^{3}$ In this period, Wietrowsky concerned himself primarily with literary production. According to his obituary (a so-called elogi$u m)^{4}$ he was a very active and diligent person. His flair for languages, high intellect and great organisational skills are very evident.

Wietrowsky's rich literary production can be divided into historical, theological, philosophical and ascetic works. His philosophical writings Quaestiones philosophicae $e^{5}$ and Philosophia disputata ${ }^{6}$ are closely bound to his pedagogical activity at the universities in Olomouc and Prague; they are written in the form of theses, which the teacher would give to his students to defend during their final exams. Wietrowsky's pedagogical experience helped him in the creation of his theological works Selectae conclusiones theologicae, ${ }^{7}$ which present the sum of the subject as it was taught at the Faculty of Theology at the

1 For an introductory overview see Hosington (2014: 127-139); cf. also Ijsewijn, Sacré (1998: 488-501); Burke (2006: 25-32; 2007a: 7-38; 2007b: 65-80); Deneire (2014: 275-285).

2 Epistolae Generalium ad Nostros (1673-1758) et Soli (1678-1773), ARSI, sign. Boh. 4-9; Bohemiae catalogi breves (1677-1737), ARSI, sign. Boh. 90-92; Catalogi triennales Provinciae Bohemiae Societatis Jesu I, II (1678-1737), ARSI, sign. Boh. 19-57; Annuae Provinciae Bohemiae Societatis Jesu (1702-1717), ARSI, sign. Boh. 114-130.

3 Franciscus Ferdinandus Khuenburg (1651-1731) strongly promoted the canonization of St. John of Nepomuk.

4 Annuae Provinciae Bohemiae Societatis Jesu ad annum 1737, ARSI, sign. Boh. 156, p. 9-10.

5 Wietrowsky (1697a).

6 Wietrowsky (1697b). Cf. Doyle (2012: 82-91); however, Doyle mistakenly views Wietrowsky as a Polish Jesuit.

7 Wietrowsky (1726-1729). 
time and, therefore, could serve as textbooks for students. In his other works, Wietrowsky discusses the spiritual exercises of Ignatius of Loyola (Momenta rationum), ${ }^{8}$ in the Latin translation of an Italian text La Vocazione vittorios $a^{9}$ he describes spiritual exercises for youth (Vocatio victoriosa) ${ }^{10}$ or presents an almost intimate work about the peaceful life to be had in a convent, dedicated to a friend who entered the consecrated life (Methodus vivendi). ${ }^{11}$

The largest part of Wietrowsky's works are historiographic texts with a focus on the history of the Church in Europe. ${ }^{12}$ He wrote a number of texts that describe the heretical movements (Historia de Arriana haeresi, Historia de haeresi iconoclastarum, Historia de haeresi Lutherana, Historia de haeresi Calviniana), ${ }^{13}$ conflicts of doctrines (Historia de magno schismate Graecorum, Historia de Bello sacro pro liberanda Terra sancta, Historia de magno schismate Occidentis, Historia de schismatibus) ${ }^{14}$ and ecumenical councils (Historia de conciliis oecumenicis) ${ }^{15}$ and took an interest in papal primacy (Historia de primatu et praerogativis Episcopi Romani) ${ }^{16}$ and biographies of the Popes (Historia S. Gregorii Magni, Historia S. Leonis Magni). ${ }^{17}$ All these histories were rather unusually published in two formats $\left(12^{\circ}\right.$ and $\left.2^{\circ}\right)$, while thematically related folio prints were bound into convolutes. In the dedication of the first of these works, Historia de Arriana haeresi, Wietrowsky hints at the source for his text. ${ }^{18}$ It was the work of a French Jesuit historian of the Church, Louis Maimbourg (1610-1686), ${ }^{19}$ whose books were indexed as prohibited and Pope Innocent XI ordered his expulsion from the Jesuit order. Perhaps it was this conflict with Rome that prevented Wietrowsky from directly naming his source. Nevertheless - as the comparison with the French original Histoire de l'Arianisme ${ }^{20}$ proves - he translated the whole original work from French to Latin, almost word for word. He preserved the original structure and the introductory synopsis, only slightly altered the text itself and also borrowed the original references to sources in the marginalia.

As the quotation from the dedication suggests, a number of other works by Wietrowsky, published in Prague between 1723 and 1731, also draw from the work of the French scholar. The most remarkable among these is a treatise on papal primacy, Historia de primatu et praerogativis Episcopi Romani. Considering the fact that the French original of this work Traité historique de l'établissement et des prérogatives de l'Eglise de Rome ${ }^{21}$

8 Wietrowsky (1700a; 1725b).

9 Pinamonti (1694). Giovanni Pietro Pinamonti (1632-1703), Italian Jesuit, missionary and writer more in Backer, Backer, Sommervogel (1905c: 763-792).

10 Wietrowsky (1700b; 1725c).

11 Wietrowsky $(1722 ; 1729 b ; 1740)$.

12 For a more detailed discussion of Wietrowsky's historiographic works, see Bočková (2015b: 219-245).

13 Wietrowsky (1723a); Wietrowsky (1723b); Wietrowsky (1724c); Wietrowsky (1725a).

14 Wietrowsky (1723c); Wietrowsky (1724a); Wietrowsky (1724b); Wietrowsky (1731a).

15 Wietrowsky (1730a).

16 Wietrowsky (1731b).

17 Wietrowsky (1726); Wietrowsky (1730b).

18 Wietrowsky (1723a: dedication): Novit Sua Reverendissima Celsitudo [i.e. Ferdinand Khuenburg] fontem Gallicum, ex quo historiae istius Latino sermone compendium deduxi, ut etiam linguae Gallicae ignaris prodessem. Aliae quoque ex eodem fonte historiae de haeresi iconoclastarum, de magno schismate Graecorum, de Bello sacro pro Terra sancta recuperanda, de magno schismate Latinorum, de haeresi Lutherana et Calviniana, in compendium Latinum reductae, praelum, si Superi faverint, exspectant.

19 See Backer, Backer, Sommervogel (1905b: 343-356).

20 Maimbourg (1673).

21 Maimbourg (1685). 
was a direct incentive for Maimbourg's expulsion from the Order, it is rather surprising that Wietrowsky was able to publish its Latin version. As follows from the Jesuit order correspondence, the translation underwent an excruciating approval process through the General of the Order, in Rome. ${ }^{22}$ Unlike other texts from the corpus, this translation deviates substantially from the French original. A detailed comparative analysis of both texts will certainly bring useful insights into the opinions of both authors on the primacy in the Roman Catholic Church, papal infallibility or supremacy over councils and so forth.

\section{Historia S. Joannis Nepomuceni}

Wietrowsky's work Historia S. Joannis Nepomuceni23 can, in effect, be counted among both types of translations mentioned in the introduction (it is a translation into Latin through its genesis, and a translation from Latin into vernacular languages through later textual tradition). It was published anonymously, nevertheless, it appears in the contemporary printed list of Wietrowsky's works as the last entry in the Historica section. ${ }^{24}$

In the Baroque era, the cult of John of Nepomuk was an indispensable part of Bohemian religious life and the ceaseless efforts to officialise the cult climaxed in 1729 with the eagerly awaited canonisation of John. He quickly became the most worshipped of the Czech saints, revered as a defender of the Seal of Confession and the patron of good reputation, both within and beyond the geographical boundaries of Bohemia. Together with grand festivities, processions, sermons, oratories, dramatic works, paintings and sculptures, the new Saint inspired a number of historiographic and legendist works.

According to the minutes of the Consistory meeting, the Prague Archbishopric also decided to shield the publication of the official text on Nepomuk and entrusted the task to Wietrowsky. ${ }^{25}$ Apart from the Latin original, the German ${ }^{26}$ and Czech $^{27}$ translations $^{2}$ appeared one year later and, in 1731, even a French translation. ${ }^{28}$ The minutes suggest that Wietrowsky was the author of the Latin version of the work and probably also of its German mutation; there is no evidence about the Czech version of the text. The existence of the French version is a very significant discovery since the text has, until recently, been

22 Epistolae Generalium ad Nostros, ARSI, sign. Boh. 7/2, f. 286r-286v (14 May 1729): Cum ipse libri titulus, qui inscribitur Historia de primatu et praerogativis Episcopi Romani, eam videatur exhibere materiam, ex qua alii forte occasionem capere possunt nos arguendi, desidero a $R$. V., ut nobis transmittatur prius revidendus; Epistolae Generalium ad Nostros, ARSI, sign. Boh. 7/2, f. 296r (25 March 1730): Cum R. V. securum me reddat de correctis omnibus in libro de primatu et praerogativis Romani Pontificis, quae occasionem criminandi dare possent, per me illum licebit typis dare.

23 Wietrowsky (1729a).

24 This list is glued into the volume Methodus vivendi, stored in the Bayerische Staatsbibliothek München, sign. 2 J.can.p. 284.

25 Prothocollum Reverendissimi Archiepiscopalis Pragensis Consistorii 1717-1737, NA ČR, Archive of the Prague Archbishopric, sign. A 21/7, f. 156r (19 May 1729): Cum diversae prodeant deductiones de vita S. Joannis Nepomuceni, ut aliqua deductio idiomatis Latini et Germanici sumptibus Reverendissimi Capituli Metropolitani authoritate Ordinarii componeretur et imprimeretur, cujus rei deductio R. P. Wietrowsky commissa fuit.

26 Geschichts-Beschreibung (1730).

27 Zpráva historická (1730).

28 De Bar (1731). 
assumed to exist in three language variants only. ${ }^{29}$ Significantly, apart from the name of the translator, it also states the name of the author of the original text - Wietrowsky.

In addition to narrating the life, martyred death and posthumous glory of St. John of Nepomuk, the text contains accounts of charitable deeds and miracles (e.g. curing of various ailments, life-saving, defence of good reputation) which happened through Nepomuk's intercession. This is followed by a detailed description of the beatification and canonisation process, completed by hymns, prayers and an overview of the number of masses celebrated in honour of the Saint.

A detailed source analysis ${ }^{30}$ proves that Historia S. Joannis Nepomuceni is a skilful compilation, which (as was common at the time of its creation) derives from the main Nepomucene texts of the time and other literary sources. The fundamental source was the Saint's biography by the Italian Jesuit Francesco Galluzzi, Vita di San Giovanni Nepomuceno (1729). ${ }^{31}$ Wietrowsky translated this text from the Italian almost completely, supplementing it with domestic textual tradition. Above all, he drew from the Bollandist version of the Nepomucene legend, Bohuslaus Balbinus' De B. Joanne Nepomuceno (1680), ${ }^{32}$ appropriating all the constitutive elements of the narrative. In fact, he took some narrative material directly from Balbinus and some filtered through Galluzzi's text - actually translating Balbinus's text from Italian back into Latin, sometimes with the help of the original, in other parts in his own words. This compilation method caused him to use one of the sections of the Balbinus legend twice by mistake. ${ }^{33}$ Wietrowsky also equipped the text with an annotation apparatus taken from the Bollandist editors' notes in the Balbinus legend.

In the sections referring to particular miracles or examples of Nepomucene reverence and in the chapters on beatification and canonisation, Wietrowsky takes the narrative frame from the Italian source. At the same time, he draws on both manuscript and printed judicial deeds (especially Acta utriusque processus), ${ }^{34}$ witness statements, letters of recommendation and papal decrees; in the conclusion, he supplies the complete text of the Bull of Canonisation. ${ }^{35}$ The text is completed by an extensive gloss in the marginalia (the Bible, Fathers of the Church, Medieval, Humanist and Baroque authors); the notes,

29 According to the entry in Bibliografie cizojazyčných bohemikálních tisků z let 1501-1800 [Bibliography of Foreign-Language Printed Bohemica], a single copy has been preserved in a convolute of Nepomucene texts, which only contains the title page and first four pages of the French translation (Prague, Library of the Knights of the Cross with the Red Star, sign. XVIII G 10, vol. 9, adl. 32). It is therefore unclear whether the entire text was published or whether the preserved copy is a mere proof print - see http://clavius.lib.cas.cz/katalog/l.dll?cll P=383622 (acc. 1 April 2017).

30 Cf. Bočková (2015a: 80-101).

31 Galluzzi (1729). Francesco Maria Galluzzi (1671-1731), Jesuit author, mainly concerned with the biographies of saints, especially from the Society of Jesus - more in Backer, Backer, Sommervogel (1905a: 1135-1141).

32 Balbinus (1680: 667-680).

33 Wietrowsky (1729a: 65-66): Verba historici sunt: "Illud permirum neque minus certum et promulgatum: Quicunque Sancti Joannis tumulum calcarint, praesertim si contempserint, eos ipsa die infamiam incurrere et vitare non posse. Id omnium Catholicorum Pragensium nostrae et superioris aetatis consensu atque exemplis pluribus constat." Pauca hic et certiora ex plurimis afferre libet. (In marg. Balbin. in vita c. 4.); cf. Wietrowsky (1729a: 78-79): Et alius recentior scriptor, "Illud permirum, inquit, neque minus certum et pervulgatum, quicunque Beati Joannis tumulum calcarint, praesertim si contempserint, eos ipsa die infamiam incurrere et vitare non posse. Id omnium Catholicorum Pragensium nostrae et superioris aetatis consensu atque exemplis plurimis constat;" quorum aliqua descripsimus.

${ }^{34}$ Acta utriusque processus $(1721 ; 1722 ; 1725)$.

35 Benedictus XIII (1929). 
however, mostly come from Galluzzi, from the Bollandist annotations in the Balbinus legend and, above all, from the account of the beatification process. This leads us to the assumption that Wietrowsky did not necessarily work with original sources.

\section{Translation analysis}

The Czech translation of the text, Zpráva historická o životě sv. Jana Nepomuckého (Historical Report on the Life of St. John of Nepomuk), does not correspond to the Baroque custom of translations / adaptations, where the Czech variants underwent significant changes. There are no major simplifications; all parts of the original text are preserved, i.e. division into six books, statistical reports, celebratory hymns, prayers, decrees and the Bull of Canonisation. The Czech version does not differ much in size from the Latin text. The official texts, i.e. the decrees and the Papal Bull, are translated very precisely (almost word for word). The biography of Nepomuk and depiction of his various miracles is translated adequately and, in fact, rather accurately; major adjustments can be found in the quotations from the deeds, the account of the beatification process, witness statements or notarial records.

With regard to the presumed reader / recipient, the translator omits or shortens the non-fictional elements, skips complicated descriptive parts, technical specifications, descriptions of works of art etc. On the other hand, he explains unclear parts, supplies his own explanatory notes and comments or illustrates the context. He enriches the text with poetic, metaphorical, expressive or naturalistic elements; on many occasions, he supplies emotional and intimate tones, which contribute to a more pronounced 'baroquisation' of the text. The shifts in the translation point to the translator's language skill and his ability to replace a Latin idiom with an adequate Czech textual ornament (saying, simile, metaphor). Apart from taking the recipient into consideration, some of the omissions and shifts can be attributed to time pressure which probably accompanied the creation of the Czech version, as the usual omissions concern unclear passages, more complicated constructions or repetitive parts. ${ }^{36}$ From several passages where the original text was misunderstood by the translator, it is evident that the author of the Czech translation was probably not one and the same as the author of the Latin original - Maximilianus Wietrowsky.

The intended recipient of the original text was an audience with a knowledge of Latin, i.e. both the secular and religious intellectual public. Apart from the domestic scholarly public, the Latin text was, no doubt, also meant to reach the foreign audience (as many copies preserved in foreign libraries prove). ${ }^{37}$ The Czech translation - similarly to the German mutation $^{38}$ - would make the text more accessible for the domestic readership. The simplification is not very significant, however, as even for the Czech reader the text can be rather demanding, e.g. because of the historical excursions, theological notes or citations of official records. The less educated readership would settle for the narrative passages of the text - the biographical narrative and the description of individual mir-

36 For more specification and examples see Bočková (2015a: 119-142).

37 Cf. for instance the library search engine WorldCat: http://www.worldcat.org/search?qt=worldcat _org_all\&q=miraculis+S.+Joannis+Nepomuceni (acc. 1 April 2017).

38 A detailed analysis of the German translation is the task for a future research. 
acles and graces. Subsequently, the function of both texts is to be informative and educational (spreading the word about a virtuous life and martyred death; for the clerical audience, the silence and preservation of the Seal of Confession as a model to follow), but also persuasive (the importance of the veneration of saints and efficacy of their intercession) and, by all means possible, entertaining. ${ }^{39}$

\section{Conclusion}

Wietrowsky's abundant literary production comprises mostly historical compilations, in which the author benefited from his language skills - Jesuit sources prove that he could speak not only Czech and German, but also French, Italian and a little Spanish. ${ }^{40}$ Hence, he could translate or digest the works of the French historian Louis Maimbourg or of the Italian authors Giovanni Pinamonti or Francesco Galluzzi. Wietrowsky does not bring new thoughts or methods; he admits his unoriginality but does not directly refer to his essential sources. On the other hand, he often refers to other authors, works and historical sources. For the Baroque reader, originality was not a decisive quality - compilations and translations were very common at the time, even though the degree of reference to the original source varied from work to work. The main purpose was to make the texts accessible to more readers and, thus, to make more impact in the educational and instructive fields. Coherence, clarity and gradual explanation could make the text an ideal educational material.

Wietrowsky left the most significant mark in literary history with his Historia S. Joannis Nepomuceni, which was translated into several languages. In his successful Latin compilation, he managed to combine all the traditional ingredients of the Nepomucene legend, narrate old and new tales of miracles and graces and, at the same time, introduce the lesser-known facts of the canonisation proceedings to his contemporaries. He wrote in a high literary language, perfected by classical models, built on the basis of Humanist Latin and enriched with a broad scope of stylistic embellishments and rhetorical devices. The translator into Czech did justice to his Latin predecessor. He faithfully preserved the character of the original text, apart from some minor omissions which simplified the text to a certain extent; elsewhere, he imaginatively enriched the text and underlined its Baroque imagery.

In the light of the presented analysis, the Czech variant can be perceived as a translation in the contemporary sense of the word (or perhaps somewhere on the line between translation and alternative version), rather than a typically Baroque translation / adap-

39 The parallel critical edition of the Latin original and the Baroque Czech translation form the basis of the monograph Bočková (2015a: 167-511). The publication is accompanied by introductory studies about the author, the cultural and historical context, information about the cult of John of Nepomuk and, in particular, the analysis of sources and the translation method. The editor's note stems from the current practice of publishing both Latin and Czech Early Modern texts, but it is modified with regard to the genre of the text, its specific character (Latin original and the contemporary Czech translation) and the aim of the edition. The main goal is to enhance comprehensibility for the reader while preserving the individual peculiarities and features typical for the time.

40 Catalogi triennales Provinciae Bohemiae Societatis Jesu I, ARSI, sign. Boh. 34, f. 6v, no. 12 (1705): callet Bohemicam, Germanicam, Italicam, Gallicam et aliquid Hispanicam. 
tation with large textual shifts. By incorporating the work into the context of the canonisation celebration, Historia S. Joannis Nepomuceni and its translations into vernacular languages, became one of the accompanying parts of the festivities. The text therefore perfectly fulfilled the requirements for religious literature, as it served the education and entertainment of its readers to the fullest.

\title{
REFERENCES
}

\author{
Abbreviations of archives \\ ARSI $=$ Archivum Romanum Societatis Iesu \\ NA ČR = Národní archiv České republiky [Czech National Archives]
}

\begin{abstract}
Manuscript sources
Annuae Provinciae Bohemiae Societatis Jesu (1702-1717), ARSI, sign. Boh. 114-130.

Annuae Provinciae Bohemiae Societatis Jesu ad annum 1737, ARSI, sign. Boh. 156.

Bohemiae catalogi breves (1677-1737), ARSI, sign. Boh. 90-92.

Catalogi triennales Provinciae Bohemiae Societatis Jesu I, II (1678-1737), ARSI, sign. Boh. 19-57.

Epistolae Generalium ad Nostros (1673-1758) et Soli (1678-1773), ARSI, sign. Boh. 4-9.

Prothocollum Reverendissimi Archiepiscopalis Pragensis Consistorii 1717-1737, NA ČR, Archive of the Prague Archbishopric, sign. A 21/7.
\end{abstract}

\section{Printed sources}

Acta utriusque processus, 1721. Acta utriusque processus in causa canonisationis Beati Joannis Nepomuceni Martyris super fama sanctitatis, virtutum et miraculorum, uti et super casu excepto seu cultu publico, huic Beato ab immemorabili tempore ante bullam Urbani VIII. Pontif. Max. exhibito, Pragae constructa, Romae examinata et secuta beatificatione approbata. Viennae: J. B. Schilgen.

Acta utriusque processus, 1722. Acta utriusque processus in causa canonisationis Beati Joannis Nepomuceni Martyris super fama sanctitatis, virtutum et miraculorum, uti et super casu excepto seu cultu publico, huic Beato ab immemorabili tempore ante bullam Urbani VIII. Pontif. Max. exhibito, Pragae constructa, Romae examinata et secuta beatificatione approbata. [2 ${ }^{\text {nd }}$ edition.] Viennae: J. B. Schilgen.

Acta utriusque processus, 1725. Acta utriusque processus in causa canonisationis Beati Joannis Nepomuceni Martyris super fama sanctitatis, virtutum et miraculorum, uti et super casu excepto seu cultu publico, huic Beato ab immemorabili tempore ante bullam Urbani VIII. Pontif. Max. exhibito, Pragae constructa, Romae examinata et secuta beatificatione approbata. [ $3^{\text {rd }}$ edition.] Veronae: $s . t . n$.

Backer, Aug., Backer, Al., Sommervogel, C., 1905a. Bibliothèque de la Compagnie de Jésus 3. Bruxelles: O. Schepens.

Backer, Aug., Backer, Al., Sommervogel, C., 1905b. Bibliothèque de la Compagnie de Jésus 5. Bruxelles: O. Schepens.

Backer, Aug., Backer, Al., Sommervogel, C., 1905c. Bibliothèque de la Compagnie de Jésus 6. Bruxelles: O. Schepens.

Balbinus, B., 1680. 'De B. Ioanne Nepomuceno ecclesiae metropol. Pragensis S. Viti Canonico Presb. Martyre Pragae et Nepomuci in Bohemia'. In: G. Henschenius, D. Papebrochius (eds.), Acta Sanctorum Maii. Tomus III. Antverpiae: J. Meursius, 667-680.

de Bar, F., 1731. Histoire de la vie, du martire et des miracles de Saint Jean de Nepomuck, chanoine de l'eglise metropolitaine de Prague, confesseur et grand aumonier de la reine de Boheme, lequel fut precipité et submergé dans le fleuve de la Moldaw pour avoir inviolablement gardé le secret de la Confession sacramentale, écrite en langue Latine par le R. Pere Wietrowski. Prague: s. t. n.

Benedictus XIII, 1929. Constitutio, qua Beatus Joannes Nepomucenus, Presbyter et metropolitanae ecclesiae Pragensis in Regno Bohemiae Canonicus, Sanctorum Christi Martyrum Canoni adscribitur. Romae: Camera Apostolica / Pragae: M. A. Höger. 
Galluzzi, F. M., 1729. Vita di San Giovanni Nepomuceno, Canonico della Metropolitana di Praga e Martire glorioso. Roma: Komarek.

Geschichts-Beschreibung, 1730. Geschichts-Beschreibung von dem Leben, Marter-Peyn und Wunder-Wercken deß in den Moldau-Fluß wegen der mit unüberwindlicher Standthafftigkeit gehaltenen Verschwiegenheit der heiligen Beicht gestürtzt und ertränckten heil. Johannis von Nepomuck, der Haupt-Kirchen zu Prag Dohm-Herrns. Prag: C. J. Hraba.

Maimbourg, L., 1673. Histoire de l'Arianisme despuis sa naissance jusqu'a sa fin, avec l'origine et le progrés de l'heresie des Sociniens. Première partie. [2 ${ }^{\text {nd }}$ edition.] Paris: S. Mabre-Cramoisy.

Maimbourg, L., 1685. Traité historique de l'établissement et des prérogatives de l'Eglise de Rome et de ses evesques. Paris: S. Mabre-Cramoisy.

Pinamonti, G. P., 1694. La Vocazione vittoriosa. Roma: L. Pittoni.

[Wietrowsky, M.], 1697a. Quaestiones philosophicae per conclusiones ex universa philosophia decisae. Pragae: Universitas Carolo-Ferdinandea, Collegium SJ ad S. Clementem.

[Wietrowsky, M.], 1697b. Philosophia disputata, in qua comprehenduntur conclusiones ex universa philosophia doctrinis philosophicis illustratae, authoritatibus firmatae, rationibus roboratae et ab argumentis contrariis vindicatae. Pragae: Universitas Carolo-Ferdinandea, Collegium SJ ad S. Clementem.

Wietrowsky, M., 1700a. Momenta rationum de utilitate exercitiorum S. P. Ignatii de Lojola ex variis authoribus Societatis Jesu collecta. Pragae: J. C. Gerzabek.

Wietrowsky, M., 1700b. Vocatio victoriosa, opusculum spirituale, in quo deteguntur insultus, quibus juvenes a Deo vocati ad Religionem infestantur et simul exhibetur ars eos vi[ $[\mathrm{n}]$ cendi. Pragae: J. C. Gerzabek.

Wietrowsky, M., 1722. Methodus vivendi cum tranquillitate in sacro claustro, ad amicum sacram ingressurum Religionem a religioso vero amico conscripta. Pragae: W. Wickhart.

Wietrowsky, M., 1723a. Historia de Arriana haeresi in compendium reducta et tomis quatuor comprehensa. Pragae: W. Wickhart.

Wietrowsky, M., 1723b. Historia de haeresi iconoclastarum in compendium reducta et tomis duobus comprehensa. Pragae: C. J. Hraba.

Wietrowsky, M., 1723c. Historia de magno schismate Graecorum in Oriente in compendium reducta et tomis duobus comprehensa. Pragae: C. J. Hraba.

Wietrowsky, M., 1724a. Historia de Bello sacro pro liberanda Terra sancta in compendium reducta et tomis tribus comprehensa. Pragae: C. J. Hraba.

Wietrowsky, M., 1724b. Historia de magno schismate Occidentis in compendium reducta et tomis duobus comprehensa. Pragae: C. J. Hraba.

Wietrowsky, M., 1724c. Historia de haeresi Lutherana in compendium reducta et tomis duobus comprehensa. Pragae: C. J. Hraba.

Wietrowsky, M., 1725a. Historia de haeresi Calviniana in compendium reducta. Pragae: C. J. Hraba.

Wietrowsky, M., 1725b. Momenta rationum de utilitate exercitiorum S. P. Ignatii de Lojola ex variis authoribus Societatis Jesu collecta. Pragae: C. J. Hraba.

Wietrowsky, M., 1725c. Vocatio victoriosa, opusculum spirituale, in quo deteguntur insultus, quibus juvenes a Deo vocati ad Religionem infestantur et simul exhibetur ars eos vi[n]cendi. Pragae: C. J. Hraba.

Wietrowsky, M., 1726. Historia de gestis praecipuis in pontificatu S. Gregorii Magni in compendium reducta et tomis duobus comprehensa. Pragae: C. J. Hraba.

Wietrowsky, M., 1726-1729. Selectae conclusiones theologicae doctrinis illustratae, authoritate munitae, ratione firmatae nec non solutione objectionum roboratae. Pragae: C. J. Hraba.

[Wietrowsky, M.], 1729a. Historia de vita, martyrio et miraculis S. Joannis Nepomuceni, Canonici Pragensis, ob sacramentalis confessionis secretum invicta constantia servatum in Moldavam fluvium dejecti et submersi. Pragae: C. J. Hraba.

Wietrowsky, M., 1729b. Methodus vivendi cum tranquillitate in sacro claustro, ad amicum sacram ingressurum Religionem a religioso vero amico conscripta. Pragae: C. J. Hraba.

Wietrowsky, M., 1730a. Historia de conciliis oecumenicis seu generalibus in compendium reducta et tomis duobus comprehensa. Pragae: C. J. Hraba.

Wietrowsky, M., 1730b. Historia de praecipuis gestis in pontificatu S. Leonis Magni in compendium reducta et tomis duobus comprehensa. Pragae: C. J. Hraba.

Wietrowsky, M., 1731a. Historia de schismatibus, quibus Ecclesia Dei praesertim a saeculo nono affligebatur, in compendium reducta. Pragae: C. J. Hraba. 
Wietrowsky, M., 1731b. Historia de primatu et praerogativis Episcopi Romani seu Summi Pontificis Ecclesiae universalis in compendium reducta, ubi demonstratur ejusdem Pontificis e Cathedra docentis infallibilitas et supra omnia concilia superioritas. Pragae: C. J. Hraba.

Wietrowsky, M., 1740. Methodus vivendi cum tranquillitate in sacro claustro, ad amicum sacram ingressurum Religionem a religioso vero amico conscripta. Pragae: Universitas Carolo-Ferdinandea, Collegium SJ ad S. Clementem.

Zpráva historická, 1730. Zpráva historická o životè, mučedlníctví a zázracích sv. Jana Nepomuckého, kanovníka pražského, pro svátostní tajnost a mlčení svaté zpovědi nepremožitedlně a stále zachovanou do řeky Moldavy neb Vltavy vhozeného a utopeného [Historical report on the life, martyrdom and miracles of St. John of Nepomuk...]. Praha: K. J. Hraba.

\title{
Secondary sources
}

Bočková, A., 2015a. Historia S. Joannis Nepomuceni. Zpráva historická o životě sv. Jana Nepomuckého aneb Podoby barokního prekladu [Historical report on the life of St. John of Nepomuk, or Forms of Baroque translation]. Praha: Scriptorium.

Bočková, A., 2015b. 'Maximilianus Wietrowsky und seine Geschichtswerke’. In: H. Bachhofer, K. Bobková-Valentová, T. Černušák (eds.), Ordenshistoriographie in Mitteleuropa. Gestaltung und Wandlung des institutionalen und persönlichen Gedächtnisses in der Frühen Neuzeit [= Monastica historia 2]. St. Pölten / Praha: Historický ústav AV ČR, 219-245.

Burke, P., 2006. 'The Jesuits and the Art of Translation in Early Modern Europe'. In: J. W. O'Malley et al. (eds.), The Jesuits 2: Cultures, Sciences, and the Arts, 1540-1773. Toronto: University of Toronto Press, 25-32.

Burke, P., 2007a. 'Cultures of Translation in Early Modern Europe'. In: Burke, Po-chia Hsia (2007: 7-38).

Burke, P., 2007b. 'Translations into Latin in Early Modern Europe'. In: Burke, Po-chia Hsia (2007: 65-80).

Burke, P., Po-chia Hsia, R. (eds.), 2007. Cultural Translation in Early Modern Europe. Cambridge: Cambridge University Press.

Deneire, T., 2014. 'Neo-Latin and the Vernacular: Methodological Issues'. In: Ford, Bloemendal, Fantazzi (2014: 275-285).

Doyle, J. P., 2012. On the Borders of Being and Knowing. Some Late Scholastic Thoughts of Supertranscendental Being. Ed. V. M. Salas. Leuven: Leuven University Press.

Ford, Ph., Bloemendal, J., Fantazzi, Ch. (eds.), 2014. Brill's Encyclopaedia of the Neo-Latin World. Leiden / Boston: Brill.

Hosington, B. M., 2014. 'Translation and Neo-Latin'. In: Ford, Bloemendal, Fantazzi (2014: 127-139).

Ijsewijn, J., Sacré, D., 1998. Companion to Neo-Latin Studies 2. Literary, Linguistic, Philological and Editorial Questions. Leuven: Leuven University Press, 488-501.

\section{HISTORIA S. JOANNIS NEPOMUCENI (1729) A JEJÍ DOBOVÝ PŘEKLAD V KONTEXTU BAROKNÍHO PŘEKLADATELSTVÍ}

Studie se věnuje dílu jezuitského historika Maximiliana Wietrowského Historia S. Joannis Nepomuceni (1729) a jeho českému překladu Zpráva historická o životě sv. Jana Nepomuckého (1730). Vychází z dosavadních výsledů bádání o raněnovověké latinské a české literatuře, která zůstala i v 17. a 18. století součástí evropské kulturní sféry, a proto často vznikají vícejazyčná vydání děl (především latinská, česká a německá). Kromě pramenné a překladatelské analýzy obou spisů zachycuje studie i další Wietrowského tvorbu v širším kulturněhistorickém kontextu.

\author{
Alena Bočková \\ Charles University, Prague \\ alena.bockova@ff.cuni.cz
}

